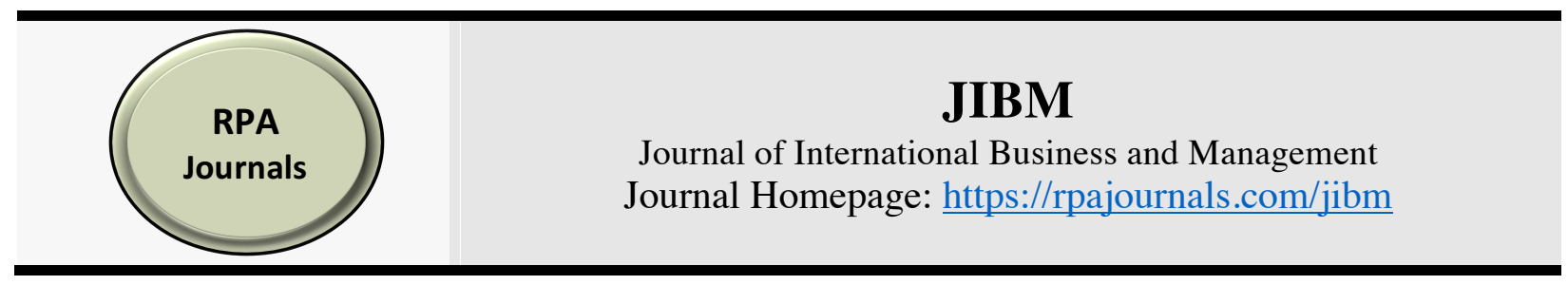

\title{
Leadership Style for Generation Y in Today's Workforce, a Case of Malaysia
}

\author{
Muhammad Rozien Zakwan Bin Ab Rahman ${ }^{2}$ \\ Amer Hamzah Jantan ${ }^{2}$ \\ School of Business and Economics ${ }^{1,2}$ \\ University Putra Malaysia (UPM), Malaysia'
}

\begin{abstract}
The main purpose of this research is to determine the preferred leadership style(s) among Generation Y. With changes in the workforce, a new approach in leadership is needed. This is to ensure the leader's strategy will be compatible with the workforce. The respondents of this study are focusing on generation $\mathrm{Y}$, which age is between 18 to 32 years old who works in the government and private sector around Selangor and Kuala Lumpur, Malaysia. The primary data source is using a questionnaire that was distributed randomly among generation Y around Selangor and Kuala Lumpur, Malaysia. The analysis of the data was tested using SPSS software. This study found out that Generation Y more preferred Ethical Leadership than Transformational or Servant Leadership. This prove that Generation Y needs new style of leadership to become more productive.
\end{abstract}

Keywords: Transformational Leadership, Ethical Leadership, Servant Leadership, Generation Y, Malaysia

\footnotetext{
*Corresponding author: Muhammad Rozien Zakwan Bin Ab Rahman Email: zakwan_rahman@yahoo.com
}

\section{DOI: https://doi.org/10.37227/JIBM-2019-04-72}

\section{Introduction}

As Baby Boomers and Gen Xs are retiring and exiting the workforce, Gen Ys, born between 1980 - 1999, are rapidly entering the workforce. According to the data by the Department of Statistics of Malaysia, 2014, approximately 50\% of the labour force is aged 34 years and below. With individuals from the Baby Boomers approaching retirement and about $20 \%$ of Gen $\mathrm{X}$ is predicted to retire by 2025 , the number is expected to increase to $75 \%$ within a relatively short span. Their entry into the workforce in large quantities has given them the power to reshape the rules of play at work. This phenomenon has ignited concerns from academics and practitioners alike over the ramification this new generation may have on our 21st-century workplaces.

We have heard so much about the notorious reputation of Gen Y employees, whereby they are perceived to want flexibility and autonomy yet desire directive and frequent feedback from their leaders (Morton, 2002). Cash and rewards are their main motivating 
factor yet work-life balance and social contribution is key to a more satisfying job (De Han and Xikun Su, 2011; Ng et al., 2010). As highlighted by Downe et al. (2012), these contrasts of characteristics of Gen Y have led the managers in a state of irony. Given this dilemma, leaders are finding it challenging to manage the Gen Ys effectively. Many Malaysian CEOs have lamented that Gen Ys do not stay long enough in one company, more so be in a job for them to be groomed as successors (Taing, 2013).

Today's workforce is more diverse than ever. Age diversity is of interest, as the workforce is now comprised of four generations (Kyles, 2005). Generational differences are a legitimate diversity issue that organizations need to recognize and understand (Arsenault, 2004). Each generation is distinct, to some extent, in terms of their core values and work values (Salahuddin, 2010). Generation Y is the newest generation of workers to enter the labour force. They are different from other generations in terms of work-related values and attitudes; managers need to tailor their approach to leading Generation $Y$ to engage and retain this generation (Salahuddin, 2010).

\section{Problem Statement}

As Generation Y continues to mature and enter the workforce, organizations and leaders must develop an understanding of how to maximize their contribution to the workplace. Employers must understand what this generation expects from all aspects of their employment, from leadership preferences to work-life balance. It is of interest to understand the impact of generational differences on preference for leadership styles as it is suggested that leaders can adjust their behaviours in practical ways to enhance subordinates' organizational commitment and performance, to increase organizations' productivity (Limsila \& Ogunlana, 2008).

While existing studies have examined the leadership styles of managers, there is a lack of evidence on the specific leadership preferences of Generation Y. Understanding what distinguishes Generation $\mathrm{Y}$ from other generations is important to develop current and future leaders (Arsenault, 2004). Much of the existing literature regarding the preferences of Generation $\mathrm{Y}$ is many years old since Generation $\mathrm{Y}$ is still maturing and continuing to enter the workplace, the data is potentially out of date. Furthermore, much of the current literature examines the strategies currently employed by leaders while failing to investigate Generation Y's perceptions of the ideal leader.

The rise of today's generation Y affects both organizations and leaders. While Gen Y ploughs on to mature and enter the workforce it is of interest for employers to develop an understanding towards all the employment facets this generation expects (Limsila \& Ogunlana, 2008 as cited in Horeczy et al., 2011, p. 1). A more productive and forwardthinking company must recognize that being able to understand leadership preferences by generation and then training to match the style as appropriate will provide these organizations with a true competitive advantage (Cates et al., 2013).

The factor age is of specific interest because today's labor force contains four different generations (Kyles, 2005, p. 53). Differences among generations include a diversity issue, which organizations must identify and comprehend (Arsenault, 2004). To maintain the balance between different groups of employees and to pander a harmonious working environment creates challenges for managers (Spiro, 2006; Srivastava \& Banerjee, 2016). Misunderstanding differences in generational cohorts can have an impact on employee performance and the actual contentment. It is, therefore, crucial for managers to learn more about their staff as different generations coalesce in their work environment (Gibson, Greenwood \& Murphy, 2010; Kaifi et al., 2012; Smith \& Nichols, 2015). 
Furthermore, it is authoritative for businesses to understand generational differences (Barclays, 2017). These generational distinctions encompass a complex collocation of behaviors. Every generation possesses unique work ethics and perspectives but also preferences towards managing and being managed as well as a certain working style and viewpoints on loyalty and working times (Yeong Lin \& Huang, 2008).

The goal of this study is to examine the leadership preferences of Generation $Y$ to help maximize their contribution to an organization. More specifically, this study aims to identify preferred leadership styles, and specific leadership attributes valued by Generation Y. Our research will contribute to the current knowledge by focusing on Generation Y when they are at a stage in their lives where leadership preferences are more established. This is significant because Generation Y should now have additional work experience and more exposure to various types of leaders and leadership styles. A survey was developed and distributed to members of Generation $\mathrm{Y}$ to determine the top attributes and leadership preferences that the generation is looking for.

This study will focus on the Malaysian context, particularly looking at the leadership preferences of Generation Y employees that are working in the private sector. The private sector was chosen because it is within this sector where high turnover and issues of retention of employees are more prevalent in Malaysia. The studies on Generation Y in the Western literature investigating Western samples would not apply to the Malaysian context.

With the increased popularity of the generation gap concept, it is argued that each of the three existing generation workforces (i.e., Baby boomers, Generation X and Generation Y) was exposed to distinctive fundamental life events that have shaped their peer personalities and values or work values, which are durable and resistant to change (Howe \& Strauss, 2007). Armstrong-Stassen and Lee (2009) and Cogin (2012) highlight that it is important for organisations to be conscious of generational diversity and to initiate the necessary actions to enhance employees' sense of belonging to the organisation. Studying this subject in work-related constructs would have implications for managers and business practices such as engagement, retention and motivation strategies, stress and performance management strategies, workforce planning, job design and broader organizational goals and expectations.

\section{Literature Review}

According to Angeline (2011), every generation of employees is unique, valuable, and special. Each tends to view the other differently based on their own life experiences and expectations. A study by Yusoff \& Kian (2013) confirmed that "generation cohorts have their groups of characteristics, aspirations, and workplace expectations. According to Benson \& Brown (2011), generations have different characteristics. It is seen that the new generations learn from the past of the older generation and be unique of that generation (Erickson, 2009). Moreover, a generation is considered as one factor of many that show each identity.

The terms Generation Y and millennial are interchangeable throughout this study. Aruna and Anitha (2015) noted that common motivators such as career development, job satisfaction, style of management, nature of the working style, and work environment play a role in the retention of Generation Y members. Knowledge about Generation Y leaders is lacking. A Deloitte survey from 2016 indicated that 57\% of millennial leaders are likely to leave their current position by 2020 (The 2016 Deloitte, 2016). This statement may be a concern for executive team members who manage 
Generation Y leaders, due to the high cost of attrition in the service industry. The findings of the study encapsulated the mission of social change by providing ways to decrease Generation Y leaders' attrition rate through motivation strategies that increase satisfaction. Losing Generation Y leaders is a concern due to the cost associated with attrition and the ways retention can improve in a service organization. Using motivation strategies to increase satisfaction will likely decrease attrition for Generation Y leaders. Motivation strategies will benefit social change by decreasing attrition in Generation Y while improving executive leadership's awareness of this concern.

\section{Leadership}

The study of leadership, like the study of generations, has been an important and central part of the literature on management and organizational behavior for several decades. The books, articles, and papers about leadership number in the several thousand and can be found in several disciplines, including management, psychology, sociology, political science, public administration, and educational administration (Yukl, 1989). Today, interest in leadership research remains keen. For instance, the Harvard Business Review alone has published nearly 500 articles since 1923 that reference leadership in their abstracts. Leadership is a complex phenomenon that has inspired many theories and definitions. However, there is no single definition of leadership that is universally applicable. There has been a wide range of definitions, theories, and models within this field, but the little consensus among leadership theorists (Lorsch, 2010).

According to Yukl (1989), there are many definitions of leadership. It has been defined in terms of leader behavior, individual traits, interaction patterns, follower perceptions, role relationships, influence on organizational culture, influence on task goals, and influence over followers. Yukl (1989) argues further that most definitions involve a social influence process whereby intentional influence is exerted by one person over other people to structure the activities and relationships in a group or organization. However, researchers usually define leadership according to their points of view and the aspect of the phenomenon that is of most interest to them. This results in discrepancies between the definitions and a lack of conceptual agreement among researchers regarding leadership, which makes it a complex, multifaceted phenomenon (Yukl, 1989).

Burns (1978), cited in Yukl (1989), similarly remarks that "leadership is one of the most observed and least understood phenomena on earth." This problem arises not only in understanding the operation of the theory but also in its definition. This is emphasized by Stogdill (1974), cited in Yukl (1989), who concludes after a comprehensive review of leadership literature that "there are almost as many definitions of leadership as those who have attempted to define the concept." We agree with Yukl (1989), who states that it is better to use the various conceptions of leadership as a source for different perspectives on a complex phenomenon than to resolve the controversy over the appropriate definition of leadership (Yukl, 1989). For this paper, leadership is defined, according to Yukl (2010), as "the process of influencing others to understand and agree about what needs to be done and how to do it, and the process of facilitating individual and collective efforts to accomplish shared objectives" (Yukl, 2010, p. 26).

\section{Methodology}

The targeted participants were generation $\mathrm{Y}$ in Malaysia. Three hundred eighty-four respondents of the age range from 17 to 36 , and currently engaging in the workforce were selected to participate in the survey. From the responses the researchers received, 214 were 
female respondents, and 170 were males. The majority of the respondents were aged from $22-26(135,35.2 \%)$. Those aged between 27-31 years old constituted 132 of the total respondents, representing $34.4 \%$ of the samples. As for the other age groups, those aged from 17-21 were 43 respondents, aged 22-26 were 135 respondents, and 74 respondents were aged from 32-36. For the length of service, most of the respondents were having 3-5 years of experience (136), followed by above 5 years (121), 1-2 years (79) and below 1 year (48). Majority of the respondents were junior executives $(110,28.6 \%)$, followed by executives $(87,22.7 \%)$, senior executives $(79,20.6 \%)$, managers $(67,17.4 \%)$ and senior managers $(41$, $10.7 \%)$. For the level of education, 183 respondents $(47.7 \%)$ possessed a degree and 86 respondents $(22.4 \%)$ were with a diploma. 65 respondents follow this with SPM certificate $(16.9 \%)$, Masters $(47,12.2 \%)$ and doctorate $(3,0.8 \%) .1-2$ years of experience.

\section{Method and Instruments}

This study is quantitative, which used a survey as the research method. The sampling method was referred to as the Krejcie and Morgan (1970) table, whereby if the population is more than 1 million, the sampling size required would be 384 respondents. The measures of organizational citizenship behaviour were adapted from Fox and Spector (2011). Measures for turnover intention were adopted from Lee (2008). Likert scale was used to measure all the study variables. The scale was anchored by 1 (Strongly disagree), 2 (Disagree), 3 (Neutral), 4 (Agree) and 5 (Strongly agree).

Three instruments were used to measure relationships. The MLQ was used to measure to what extent the transformational leadership style motivates Millennial generation employees. This instrument has been frequently used to conduct studies related to transformational and transactional leadership internationally (Dimitrov \& Darova, 2016) and has been extensively researched and validated (Mind Garden, 2017. Using a 5-point Likert scale with the MLQ instrument, higher scores translated into facilitating motivation and lower scores translated into not facilitating motivation. The ELW was used to measure to what extent the ethical leadership style motivates Millennial generation employees. This instrument is new in comparison to the MLQ but has been successfully validated (Kalshoven et al., 2011). The ELW also uses a 5-point Likert scale with higher scores translating into facilitating motivation and lower scores, translating into not facilitating motivation. The SL7 instrument was used to measure to what extent the servant leadership style motivates Millennial generation employees. A 28-item version of this instrument was introduced by Liden et al. (2008), and further refined to a 7-item instrument and validated in 2014. (Liden et al., 2014). The SL-7 uses a seven-point Likert scale with the high scores translating into facilitating motivation and the low scores translating into not facilitating motivation.

Based on the above information, the following hypotheses were developed for testing.

Hypothesis 1: Transformational leadership has a significant positive effect on Generation Y in the workplace.

Hypothesis 2: Ethical leadership has a significant positive effect for Generation $\mathrm{Y}$ at the workplace.

Hypothesis 3: Servant leadership has a significant positive effect for Generation $\mathrm{Y}$ at the workplace. 


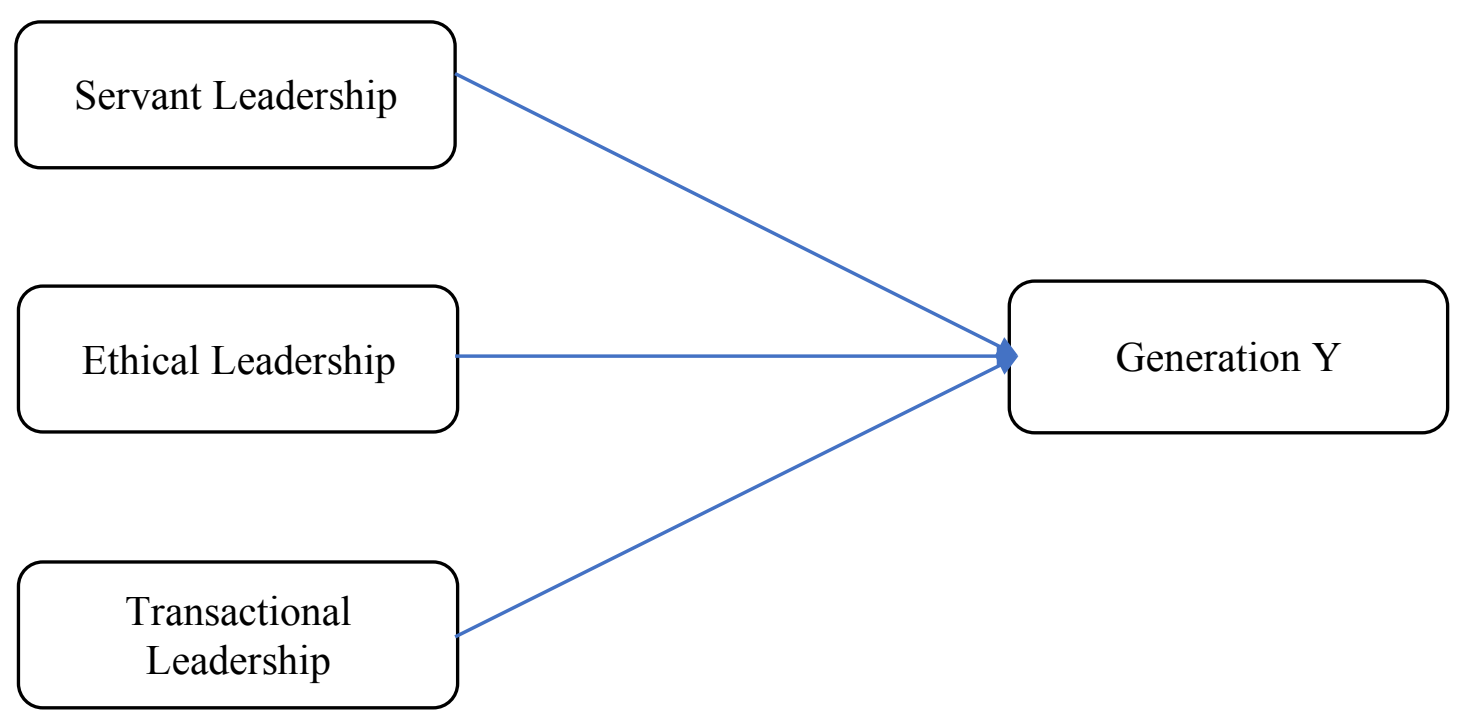

Figure 1: Research Framework

\section{Data Analysis}

Data analysis in the present study was conducted by using Statistical Package for Social Science (SPSS). Factor analysis was selected to test the validity of the variables and to assess how well the measures represent the concept being measured (Sekaran and Bougie, 2010). The reliability test was employed to test the internal consistency of the study variables. Separately, correlation analysis and multiple regression analysis were used to examine the relationship between organizational citizenship behaviour (OCB) and turnover intention.

Table 1: Reliability test

\begin{tabular}{|l|l|}
\hline Transformational Leadership & \\
\hline Cronbach's Alpha & $\mathrm{N}$ of Items \\
\hline .832 & 10 \\
\hline Ethical Leadership & \\
\hline Cronbach's Alpha & $\mathrm{N}$ of Items \\
\hline .853 & 11 \\
\hline Servant Leadership & \\
\hline Cronbach's Alpha & $\mathrm{N}$ of Items \\
\hline .993 & 24 \\
\hline
\end{tabular}

The reliability test is finished to work out whether or not the instrument employed in this study is reliable or not and to check the consistency of the queries. Cronbach's Alpha is employed to live consistency. Consistent with Zikmund (2003), if the responsibility analysis is between zero. $7-1.0$ is considered as alright, $0.6-0.7$ considers smart, $0.5-0.6$ as average and below zero. 5 thought-about as poor. Supported the freelance variables on top of the responsibility datum for job satisfaction is zero.832. Meanwhile, responsibility statistics for organisational commitment are zero.853 and organisational culture is zero.993. Leadership behavior is zero.976. It shows our instrument and queries were reliable and consistent. 


\section{Summary Statistic of Respondents}

Demographic variables of the respondent sample were extracted by asking queries on age, gender, legal status, job position, range of years worked with the current leader, range of years of the firm of department and size of department (number of employees). The table below summarizes the demographic info of the sample population for this study.

Table 2: Demographic Statistics

\begin{tabular}{|c|c|}
\hline Demographic Variable & Percentage of Sample \\
\hline \multicolumn{2}{|l|}{ Age } \\
\hline $20-29$ years & 43.9 \\
\hline $30-39$ years & 44.4 \\
\hline $40-49$ years & 11.8 \\
\hline \multicolumn{2}{|l|}{ Gender } \\
\hline Male & 48.9 \\
\hline Female & 51.1 \\
\hline \multicolumn{2}{|l|}{ Education Level } \\
\hline Secondary & 3.8 \\
\hline Diploma & 57.8 \\
\hline Postgraduate & 30.4 \\
\hline \multicolumn{2}{|l|}{ Marital Status } \\
\hline Single & 58.9 \\
\hline Married & 41.1 \\
\hline \multicolumn{2}{|l|}{ Job Position } \\
\hline Administrative or clerical & 6.4 \\
\hline Technician & 3.0 \\
\hline Executives or senior executive & 37.3 \\
\hline Assistant manager & 10.6 \\
\hline Managers or senior manager & 28.0 \\
\hline Others & 14.8 \\
\hline \multicolumn{2}{|l|}{$\begin{array}{c}\text { Number of years working with } \\
\text { current employer }\end{array}$} \\
\hline Less than 3 years & 45.6 \\
\hline $3-6$ years & 43.0 \\
\hline $7-10$ years & 11.4 \\
\hline \multicolumn{2}{|l|}{ Type of organization } \\
\hline Manufacturing & 11.4 \\
\hline Service & 58.6 \\
\hline Others & 30.0 \\
\hline \multicolumn{2}{|l|}{$\begin{array}{c}\text { Number of years of establishment of } \\
\text { the organization }\end{array}$} \\
\hline Less than 10 years & 23.7 \\
\hline $10-15$ years & 17.8 \\
\hline More than 15 years & 58.5 \\
\hline \multicolumn{2}{|l|}{$\begin{array}{c}\text { Number of employees in the } \\
\text { organization }\end{array}$} \\
\hline Less than 10 & 34.5 \\
\hline
\end{tabular}




\begin{tabular}{|c|c|}
\hline $10-15$ & 23.4 \\
\hline $15-20$ & 10.6 \\
\hline More than 20 & 31.5 \\
\hline
\end{tabular}

\section{Correlation Test}

A correlation test was to investigate the link of the variables for the hypothesis. The man of science uses Spearman's parametric statistic to research the link between 2 or additional variables that the numerous levels are zero.05 for every tested hypothesis. Also, the parametric statistic encompasses a vary of potential values for -1 to +1 . The worth indicates the strength of the link, whereas the sign (+ or -) indicates direction. What is more, the man of science conjointly used the Guldford Rule of Thumb because the guideline to work out the strength of the link of the variable.

Table 3: Correlation Test Transformational Leadership and Generation Y

\begin{tabular}{|c|c|c|c|c|}
\hline & & & $\begin{array}{l}\text { Leadership } \\
\text { Behavior }\end{array}$ & $\begin{array}{c}\text { Organizational } \\
\text { Commitment }\end{array}$ \\
\hline $\begin{array}{l}\text { Spearman's } \\
\text { rho }\end{array}$ & $\begin{array}{l}\text { Transformational } \\
\text { Leadership }\end{array}$ & $\begin{array}{l}\text { Correlation } \\
\text { Coefficient } \\
\text { Sig. }(2 \text { tailed }) \\
\text { N }\end{array}$ & $\begin{array}{l}1.000 \\
384 \\
\end{array}$ & $\begin{array}{l}.232 \\
.000 \\
\\
384\end{array}$ \\
\hline & Generation Y & $\begin{array}{l}\text { Correlation } \\
\text { Coefficient } \\
\text { Sig. }(2 \text { tailed }) \\
\text { N }\end{array}$ & $\begin{array}{l}.232 \\
.000 \\
384\end{array}$ & $\begin{array}{l}1.000 \\
384\end{array}$ \\
\hline
\end{tabular}

\section{Hypothesis 1}

HO Transformational leadership has a significant positive effect on Generation $\mathrm{Y}$ in the workplace.

H1 Transformational leadership has a significant negative effect on Generation $\mathrm{Y}$ in the workplace.

$\mathrm{R}=.232$, Sig-value $(\mathrm{p})=.00$

Sig-value $(.000)<\mathrm{p}(0.05)$

There's weak relationship between transformational leadership and Generation $\mathrm{Y}$ at the workplace by observing the 'r' price. Since sig-value $(0.000)<p(0.005)$ therefore the finding has with success rejected the null hypothesis (H0). Therefore, $\mathrm{H} 1$ is supported.

Table 4: Correlation Test Ethical Leadership and Generation Y

\begin{tabular}{|c|c|c|c|c|}
\hline & & & $\begin{array}{c}\text { Leadership } \\
\text { Behavior }\end{array}$ & $\begin{array}{l}\text { Organizational } \\
\text { Commitment }\end{array}$ \\
\hline $\begin{array}{l}\text { Spearman's } \\
\text { rho }\end{array}$ & $\begin{array}{l}\text { Ethical } \\
\text { Leadership }\end{array}$ & $\begin{array}{l}\text { Correlation } \\
\text { Coefficient } \\
\text { Sig. }(2 \text { tailed }) \\
\text { N }\end{array}$ & $\begin{array}{l}1.000 \\
384\end{array}$ & $\begin{array}{l}.990 \\
.000 \\
384\end{array}$ \\
\hline & Generation Y & $\begin{array}{l}\text { Correlation } \\
\text { Coefficient } \\
\text { Sig. }(2 \text { tailed }) \\
\text { N }\end{array}$ & $\begin{array}{l}.990 \\
.000 \\
\\
384\end{array}$ & $\begin{array}{l}1.000 \\
384\end{array}$ \\
\hline
\end{tabular}




\section{Hypothesis 2}

H0 Ethical leadership has a significant positive effect on Generation Y in the workplace.

H1 Ethical leadership has a significant negative effect on Generation Y in the workplace.

$\mathrm{R}=.990$, Sig-value $(\mathrm{p})=.00$

Sig-value $(.000)<\mathrm{p}(0.05)$

There's a positive and extremely high relationship between ethical leadership and o Generation Y at the workplace by observing the ' $r$ ' price. Since sig-value $(0.000)<p(0.005)$, therefore, the finding has, with success, accepted the null hypothesis (H0). Therefore, $\mathrm{H} 0$ is supported.

Table 5: Correlation Test Servant Leadership and Generation Y

\begin{tabular}{|l|l|l|l|l|}
\hline \multicolumn{2}{|l|}{} & & $\begin{array}{l}\text { Leadership } \\
\text { Behavior }\end{array}$ & $\begin{array}{l}\text { Organizational } \\
\text { Commitment }\end{array}$ \\
\hline Spearman's rho & $\begin{array}{l}\text { Servant } \\
\text { Leadership }\end{array}$ & $\begin{array}{l}\text { Correlation } \\
\text { Coefficient } \\
\text { Sig. (2 tailed) } \\
\text { N }\end{array}$ & 1.000 & .452 \\
& & 384 & .000 \\
\hline & Generation Y & $\begin{array}{l}\text { Correlation } \\
\text { Coefficient } \\
\text { Sig. (2 tailed) } \\
\text { N }\end{array}$ & .452 & 384 \\
\hline & & 384 & 1.000 \\
& & & 384 \\
\hline
\end{tabular}

\section{Hypothesis 3}

H0 Servant leadership has a significant positive effect on Generation Y in the workplace.

H1 Servant leadership has a significant negative effect on Generation Y at the workplace. $\mathrm{R}=.452$, Sig-value $(\mathrm{p})=.00$

Sig-value $(.000)<\mathrm{p}(0.05)$

There's a medium-strength relationship between servant leadership behavior and Generation $Y$ at the workplace by observing the ' $r$ ' price. Since sig-value $(0.000)<p(0.005)$, therefore, the finding has, with success, accepted the null hypothesis (H0). Therefore, H0 is supported.

\section{Regression Analysis}

Table 6: Regression Analysis

\begin{tabular}{|l|c|c|c|c|c|}
\hline Model & \multicolumn{2}{|c|}{$\begin{array}{c}\text { Unstandardized } \\
\text { Coefficients }\end{array}$} & $\begin{array}{c}\text { Standardized } \\
\text { Coefficients }\end{array}$ & Sig. \\
\cline { 2 - 4 } & $\mathrm{B}$ & $\begin{array}{c}\text { Std. } \\
\text { Error }\end{array}$ & Beta & & \\
\hline 1 (Constant) & .852 & .143 & -.001 & 4.687 & .000 \\
$\begin{array}{l}\text { Transformational } \\
\text { Leadership }\end{array}$ & -.005 & .116 & .018 & .986 \\
$\begin{array}{l}\text { Ethical } \\
\text { Leadership }\end{array}$ & .390 & .120 & .500 & 3.332 & .001 \\
$\begin{array}{l}\text { Servant } \\
\text { Leadership }\end{array}$ & .373 & .085 & .499 & 3.819 & .000 \\
\hline
\end{tabular}


The regression analysis shows an issue that almost all affected by the leadership style. From the regression analysis, among the factors that almost all affected by leadership style is that the ethical leadership (.500) so follow by servant leadership (4.99) and, in conclusion, transformational leadership (-.001).

\section{Conclusions}

In starting, all hypothesizers concerning this study were proved to be right. There's a big relationship between ethical leadership style and Generation Y, there's a medium relationship between servant leadership style and Generation Y, and there is a weak relationship between transformational leadership and Generation Y.

During this study, though the correlations were statistically important ( $\mathrm{p}<$ zero.05), the number of correlations with every variable was comparatively tiny. One amongst the explanations can be that there is an alternative, probably stronger, predictors and dependents for the variables investigated during this study. As an example, there are varied factors that influence or are influenced by job satisfaction, as represented by Rad and Yarmohammadian (2006).

For future researchers, sampling was one of the restrictions known during this study. The fact that simple random sampling was used meant that results weren't directly transferable to the final operating population. Additionally, the sample subjects during this study were not entirely covered by the Malaysian population. Thus, the finding couldn't be generalized. Therefore, the future analysis may investigate extending the study population to incorporate collect input from gone through business manager.

\section{Acknowledgement}

This research is part of Doctoral thesis. The research was funded by Putra Research Grant (Vote Number: GP-IPS/2017/9583300), Research Management Center, Universiti Putra Malaysia (UPM), Malaysia.

\section{References}

Arsenault, P. M. (2004). Validating generational differences: A legitimate diversity and leadership issue. Leadership \& Organization Development Journal, 25(2), 124-141.

Aruna, M., \& Anitha, J. (2015). Employee Retention Enablers: Generation Y Employees. SCMS Journal of Indian Management, 12(3), 94.

Barclays. (2017). Barclays Bank, PLC. from https://wealth.barclays.com/global-stockandrewards/en_gb/home/research-centre/talking-about-my-generation.html.

Burns, J. M. (1978). Leadership. Harper and Row. New York.

Cates, S. V., Cojanu, K. A., \& Pettine, S. (2013). "Can You Lead Effectively? An Analysis of the Leadership Styles of Four Generations of American Employees. International Review of Management and Business Research. 2(4), 1025.

De Han \& Xikun Su (2011). "Managing Generation Y: Recruiting and Motivating”, 2011 International Conference on Management and Service Science, Wuhan, 1-4.

Dimitrov, D. Y. \& Darova, S. S. (2016). Factor Structure of the Multifactor Leadership Questionnaire MLQ5X. Strategic Impact, 58(1).

Deloitte. (2016). The 2016 Deloitte Millennial Survey. Winning Over the Next Generation of Leaders. Deloitte Touche Tohmatsu Limited. from https://www2.deloitte.com/content/dam/Deloitte/global/Documents/AboutDeloitte/gx-millenial-survey-2016-exec-summary.pdf. 
Downe, A.G., Loke S.P., Ho S.Z. \& Taiwo A.A. (2012). Corporate Talent Needs and Availability in Malaysian Service Industry. International Journal of Business Management. 7(2).

Horeczy, A., Lalani, A., Mendes, G., Scongack, T., Miller, M., \& Samsa, L. (2011). Leadership Preferences of Generation $Y$.

Kaifi, B. A., Nafei, W. A., Khanfar, N. M., \& Kaifi, M. M. (2012). A Multi-Generational Workforce: Managing and Understanding Millennials. International Journal of Business \& Management, 7(24), 88-93.

Kalshoven, D., Den Hartog, D., \& De Hoogh, A. (2011a). Ethical leadership at work questionnaire. Psyctests.

Kalshoven, D., Den Hartog, D., \& De Hoogh, A. (2011b). Ethical leadership at work questionnaire (ELW): Development and validation of a multidimensional measure. Leadership Quarterly, 22(1), 51-69.

Kyles, D. (2005). Managing Your Multigenerational Workforce. Strategic Finance. 87(6), $52-55$.

Liden, R., Wayne, S., Chenwei, L., \& Meuser, J. (2014). Servant leadership and serving culture: Influence on individual and unit performance. Academy of Management Journal, 57(5), 1434-1452.

Limsila, K., \& Ogunlana, S. O. (2008). Performance and Leadership Outcome Correlates of Leadership Styles and Subordinate Commitment. Engineering, Construction and Architectural Management. 15, 164 - 184.

Mind Garden. (n.d.). Multifactor Leadership Questionnaire (MLQ). from http://www.mindgarden.com/products/mlq.htm

Morton, L. P. (2002). Targeting Generation Y. Public Relations Quarterly. 47(2), 16-26.

Ng, E. S. W, Schweitzer, L., \& Lyons S. T. (2010). New generation, great expectations: A field study of the millennial generation. Journal of Business and Psychology, 25(2), 281-292.

Salahuddin, M., M. (2010). Generational Differences Impact on Leadership Style and Organizational Success. Journal of Diversity Management, 5(2), 1-6.

Smith, T. J. \& Nichols, T. (2015) Understanding the Millennial Generation. The Journal of Business Diversity, 15, 39-47.

Srivastava, M., \& Banerjee, P. (2016). Understanding Generation Y. Journal of Management Research. 16(3), 148-164.

Stogdill, R. (1974). Handbook of leadership: A Survey of Theory and Research. The Free Press. New York.

Taing, A. (2013). Providing Inspirational Leadership. The Edge Special Report: Engaging Gen Y, 28 January 2013.

Whitney Gibson, J., Greenwood, R. A., \& Murphy, Jr., E. F. (2009). Generational Differences In The Workplace: Personal Values, Behaviors, And Popular Beliefs. Journal of Diversity Management, 4(3), 1-8.

Yukl, G. A. (1989). Managerial leadership: A review of theory and research. Journal of Management, 15(2), 251-289.

Yukl, G. A. (2010). Leadership in Organizations (7th ed.). Pearson. Upper Saddle River, NJ.

Zikmund, W. G. (2003). Business Research Methods (7th ed.). Thomson South-Western, Ohio. 